\title{
UN Support to National Security Policy-Making from an Institution-Building Perspective
}

\author{
Vincenza Scherrer*
}

\begin{abstract}
While national security policies (NSP) are by definition national endeavours, they are increasingly supported by international actors. The United Nations (UN) is one such actor that is progressively supporting NSP development in the context of post-conflict peacebuilding. International support for what is meant to be a sensitive exercise of national policy-making is considered extremely challenging. This article provides an overview of UN support to NSP development, in order to identify both difficulties and opportunities of external, institutional support to national processes. This article posits that examining NSP development from an institution-building perspective offers an innovative way of framing external support in such national processes. In particular, it supports the understanding that the NSP-making process - and not only the NSP document - provides an opportunity to set the necessary foundations for institution-building.
\end{abstract}

Keywords: National security policy, national security strategy, United Nations, institution-building, national ownership, peacebuilding Nationale Sicherheitspolitik, nationale Sicherheitsstrategie, Vereinte Nationen, Aufbau von Institutionen, nationale Eigenverantwortung, Friedensschaffung

\section{Introduction ${ }^{1}$}

$\mathrm{N}$ ational security policies (NSP) are typically developed at the national level. In peacebuilding contexts, however, international actors are progressively involved in supporting the development of NSPs. This is because from the recipients' perspective, international support may provide much-needed skills, capacity or financial support for such resource-heavy processes. From the international perspective, the value of supporting these national efforts is recognised to be the ability to tap in at the strategic level to enhance the overall coherence of peacebuilding efforts.

The United Nations (UN) is one such actor that is progressively engaging in support to NSP development in the context of post-conflict peacebuilding. This support is contextualised within the framework of building effective and accountable security institutions. The organisation's growing interest in supporting NSP development is evident by the increasing references to national security policies and strategies in UN policy documents, ${ }^{2}$ as well as the recent development of UN technical guidance on support to such processes. ${ }^{3}$

* Vincenza Scherrer is programme manager of the United Nations and Security Sector Reform Programme at the Geneva Centre for the Democratic Control of Armed Forces (DCAF).

1 This paper draws on research led by the author as part of a project mandated by the UN Department of Peacekeeping Operations (DPKO) to support the development of a UN integrated technical guidance note on 'UN Support to National Security Policy and Strategy Making'. In order to feed practical experiences into the guidance note, DCAF commissioned case studies to examine the experience of UN support to such processes. The authors of the case studies are Sylvie More (Central African Republic), Thomas Jaye (Liberia) and Björn Hofmann (Timor-Leste). This article draws on these three draft studies and broader research that will be published in an edited volume: Vincenza Scherrer (ed.), National Security Policies and Security Sector Reform: Insights from UN Experience in the Central African Republic, Liberia and TimorLeste (Münster: LIT, forthcoming 2012). The views expressed in this paper are those of the author alone.

2 See, for instance, UN Special Committee on Peacekeeping Operations, 'Report of Substantive Session’, UN Doc. A/64/19, 22 February-19 March 2010.

3 UN Inter-Agency SSR Task Force, 'Integrated Technical Guidance Note on United Nations Support to National Security Policy and Strategy Making Processes', UN Department of Peacekeeping Operations, New York, draft, 18 October 2011.
International support to what is meant to be a sensitive exercise of national policy-making is recognised to be extremely challenging. ${ }^{4}$ It raises many questions. How to ensure national ownership in the face of national capacity gaps and tight international timelines? How to reconcile national values with international standards? Finally, what is the scope for international support in an area that touches upon 'national security', which has traditionally been seen as off limits to international efforts? ${ }^{5}$

This paper posits that 'NSP-making' should be perceived as a component of longer-term institution-building in order to enhance positive synergies between external support and national processes. Consequently, it examines UN support to NSP development from the perspective of externally assisted institution-building. It first frames NSP development within the context of institution-building. It then looks at UN support to NSP development in theory and practice, drawing on case studies of the Central African Republic (CAR), Liberia and Timor-Leste. ${ }^{6}$ Finally, the paper evaluates some of the main tensions and opportunities presented by externally driven support to NSP-making. In no way does it claim to cover all the challenges of support to NSP-making; nor does it examine institution-building in detail. Rather, with reference to concrete examples, it attempts to underline how an institution-building perspective can broaden our understanding of UN support to NSP-making processes.

For the purpose of this paper, the term of NSP refers to all documents that are nationally developed as part of a policymaking process to promote national security. This includes national security policies, national security strategies and

4 See, for instance, Edward Rees, 'Security Sector Reform (SSR) and Peace Operations: Improvisation and Confusion from the Field', external study for Peacekeeping Best Practices Section of the Department of Peacekeeping Operations (New York: UN Department of Peacekeeping Operations, 2006).

5 Claire Mcloughlin, 'Topic Guide on Fragile States', updated version, Governance and Social Development Resource Centre, International Development Department, University of Birmingham, November 2011, available at www.gsdrc.org/docs/open/CON86.pdf.

6 See note 1. 
national security plans, which are the main instruments of this kind supported by the United Nations over the years.

\section{Framing National Security Policy-Making in the Context of Institution-Building}

Institution-building can be defined as 'the planning, structuring, and guidance of new or reconstituted organizations which (a) embody changes in values, functions, physical and/or social technologies, (b) establish, foster, and protect normative relationships and action patterns; and (c) attain support and complimentarity in the environment'. ${ }^{7}$ Essentially, it represents building effective and accountable government institutions.

NSPs are linked to institution-building in two ways. First, they present a common understanding of future directions for national security-related sectors. Esman, for instance, notes that 'the institution building scheme has presupposed that when induced social change is attempted, statements of goals and of styles of action generally precede and indeed help to guide action'. 8 This idea is further addressed by Smuckler, who notes that a policy decision is first required on which institution should be strengthened or established. ${ }^{9}$ The development of NSPs can therefore be understood as a key element of institution-building, in that such documents inform strategic decision-making on the development of effective and accountable security institutions while ensuring that competing needs and priorities are considered.

Second, NSPs not only outline the strategic direction for national security, but are also crucial components of a process that seeks to form 'a common identity, ethos, culture, [and] consistent policies' - all of which are key aspects that are often lacking in post-conflict security institutions. ${ }^{10}$ In this sense, the process of building consensus around common values and a shared vision feeding into NSP development is also an essential prerequisite to building effective security sector institutions. As noted by the Governance and Social Development Resource Centre, 'trying to build institutions without linking them to shared values and inclusive notions of citizenship and political community can result in the persistence of divisions'.$^{11}$ NSPs can therefore help perform a key function of institution-

7 Milton J. Esman and Hans C. Blaise quoted in Milton J. Esman, The Institution Building Concepts: An Interim Appraisal (Pittsburgh, PA: University of Pittsburgh GSPIA, 1967), p. 1. As noted in Melvin G. Blase, Institution Building: A Source Book (Columbia, MO: University of Missouri Press, 1986), the literature 'resulted largely, but not exclusively, from the Inter-University Research Program in Institution Building'. See, for instance, Milton J. Esman and Hans C. Blaise, Institution Building Research - The Guiding Concepts (Pittsburgh, PA: University of Pittsburgh GSPIA, 1966).

8 Esman, ibid., p. 14.

9 Ralph H. Smuckler, 'Field Application of Institution Building', in Joseph W. Eaton (ed.), Institution Building and Development: From Concepts to Application (Beverly Hills, CA: Sage Publications, 1972), p. 234, quoted in Blase, note 7, p. 93.

10 Otwin Marenin, 'Restoring Policing Systems in Conflict-Torn Nations: Process, Problems, Prospects', Occasional Paper No. 7 (Geneva: Geneva Centre for the Democratic Control of Armed Force, 2005), p. 35, quoted and developed in Annika S. Hansen, 'Local Ownership in Peace Operations', in Timothy Donais (ed.), Local Ownership in Security Sector Reform (Geneva: Geneva Centre for the Democratic Control of Armed Forces, 2008), p. 51.

11 See Governance and Social Development Resource Centre, 'State-Society Relations and Citizenship', International Development Department, University of Birmingham, available at www.gsdrc.org/go/topic-guides/statesociety-relations-and-citizenship/socio-political-cohesion-and-nationhood. building: supporting a national dialogue between the state and its people to define national vision and values.

NSP-making remains an inherently sensitive process. It requires thinking about short-term needs while factoring in long-term priorities. It entails attempting to meet people's expectations while at the same time reflecting on sustainability of resources. It is also about recognising and overcoming the culture of secrecy that often dominates decision-making on security issues. Finally, it requires significant human and financial resources, which tend to be lacking in peacebuilding environments. In these contexts, external support is often relied upon to address some of the resource dilemmas. However, external support brings with it an additional layer of challenges, including risks of impinging on national ownership. For example, the process may be moulded to adapt to the capacity and timelines of external actors rather than the other way round. Moreover, there is a tendency for external actors to perceive NSP-making as an entry point for subsequent institution-building support (because NSPs are recognised to provide the strategic direction for ensuing efforts). This tendency entails the risk of missing the point that the NSP-making process - not just the document itself - provides the opportunity to set early foundations for the institution-building scheme.

\section{UN Support to NSPs}

Traditionally, states have often been reluctant to accept external assistance in the area of NSP-making. This is recognised to have been due to 'concerns about interference in domestic matters, especially one as sensitive as national security policy and strategy making'. ${ }^{12}$ This trend is beginning to change, as reflected by increasing UN engagement in support to NSPmaking processes. While references to NSPs were made in Security Council mandates in the late 1990s, it has mainly been in the past decade that the United Nations has been called upon to assist member states in developing NSPs. Such support has taken place in a wide variety of peacebuilding contexts, such as the Central African Republic, Côte d'Ivoire, Liberia, Somalia and Timor-Leste. Despite the UN's engagement in assisting NSP-making, there is a significant lacuna of information on the rationale for its support, as well as the modalities and extent of the UN's role in such processes in practice. This section will briefly review the rationale for UN support to NSPs and the type of support it has provided in practice.

\subsection{UN Support to NSPs in Theory}

UN support to NSP-making is contextualised in the organisation's support to building effective security institutions. This is reflected in the 2010 report of the Special Committee on Peacekeeping Operations, which discusses UN support to NSPs under the category of 'security sector reform' (SSR). ${ }^{13}$ The SSR focus of NSP support by the United Nations is echoed by the development in 2011 of an integrated technical

12 UN Inter-Agency SSR Task Force, note 3, p .6.

13 UN Special Committee on Peacekeeping Operations, note 2, para. 110. 
guidance note on 'UN Support to National Security and Policy Making' as part of a new set of guidance on SSR. This guidance note recognises that 'national security policies and strategies are intimately linked to SSR as they articulate the priorities for national security and the capacities required to meet them'. ${ }^{14}$

From a UN SSR perspective, supporting the development of NSPs is crucial for two main reasons. First, it represents support at the 'strategic sectoral level', which is widely viewed as the niche for UN support to SSR in peacekeeping contexts. The chief of the DPKO SSR Unit recently underlined that 'the comparative advantage of the UN lies at the sector-wide and strategic level, rather than solely at the tactical level'. ${ }^{15}$ Prioritising the development of NSPs is, therefore, the logical flow to operationalising this strategic approach to SSR. Second, it envisages support to SSR programmes that are anchored in a nationally developed vision of priorities and needs. The process of developing a common vision of national security through an NSP is thus perceived as laying 'the foundation for national ownership of SSR'. ${ }^{16}$

\subsection{UN Support to NSPs in Practice}

While the United Nations has been engaged in supporting NSPmaking processes for several years now, this support has often taken place on an ad hoc basis. Security Council resolutions explicitly mandating UN support to NSP processes are rare (see Table 1). However, support has often taken place within the context of broader mandates to support SSR in general. This was the case for instance in the CAR, Sierra Leone and TimorLeste. In addition, several UN Security Council resolutions specifically encourage the national government to engage in such policy/strategy development processes without formally assigning a role to the United Nations (e.g. the Democratic Republic of the Congo, Sudan and Guinea-Bissau).

The UN's support in this area has generally been provided through the Department of Peacekeeping Operations (DPKO) and the UN Development Programme (UNDP). UN support ranges from financial contributions to technical and political assistance throughout the process. As noted in the guidance note on this topic, UN support could theoretically encompass measures such as the conduct of a feasibility study to evaluate the need for and practicability of the process; the creation of a steering committee to guide the process; awareness-raising campaigns; the conduct of assessments and consultations; drafting; and enabling parliamentary and executive approval. ${ }^{17}$ In practice, UN support rarely encompasses the entire spectrum of the policy process, and is often geared towards filling national human and financial resource gaps.

14 UN Inter-Agency SSR Task Force, note 3, p. 8.

15 UN Department of Peacekeeping Operations, 'SSR Practitioners Complete Fourth Annual Inter-Agency Task Force Workshop', United Nations Department of Peacekeeping Operations SSR Newsletter, No. 10, April-June 2011.

16 Adedeji Ebo and Kristiana Powell, 'Why Is SSR Important? A United Nations Perspective', in Mark Sedra (ed.), The Future of Security Sector Reform (Waterloo, ON: Centre for International Governance and Innovation, 2010), p. 54.

17 See UN Inter-Agency SSR Task Force, note 3, annex three: checklist on potential steps for national security policy and strategy making processes to guide UN technical assistance to national authorities.
Table 1: Overview of explicit mandates to support NSPmaking in UN Security Council resolutions ${ }^{18}$

\begin{tabular}{|l|l|l|}
\hline $\begin{array}{l}\text { Mission/ } \\
\text { UNSC resolution }\end{array}$ & Type & Terminology \\
\hline $\begin{array}{l}\text { UN Mission in Liberia } \\
\text { SCR 1712 (Sep 2006) }\end{array}$ & $\begin{array}{l}\text { National security } \\
\text { policy }\end{array}$ & $\begin{array}{l}\text { 'Calls on the } \\
\text { Government of Liberia, } \\
\text { in close coordination } \\
\text { with UNMIL, to take } \\
\text { the necessary steps on } \\
\text { its part towards ... the } \\
\text { rapid development of a } \\
\text { national security policy' }\end{array}$ \\
\hline $\begin{array}{l}\text { UN Integrated Office } \\
\text { in Burundi (BINUB) } \\
\text { SCR 1719 (Oct 2006) }\end{array}$ & $\begin{array}{l}\text { National plan for } \\
\text { reform of securi- } \\
\text { ty sector }\end{array}$ & $\begin{array}{l}\text { 'Requests that, once } \\
\text { established, BINUB } \\
\text { focuses on and supports } \\
\text { the Government in } \\
\text { the following areas } \\
\ldots \text { Support for the } \\
\text { development of a } \\
\text { national plan for reform } \\
\text { of the security sector' }\end{array}$ \\
\hline $\begin{array}{l}\text { UN Operation in Côte } \\
\text { d'Ivoire (UNOCI) } \\
\text { SCR 2000 (Jul 2011) }\end{array}$ & $\begin{array}{l}\text { National security } \\
\text { strategy }\end{array}$ & $\begin{array}{l}\text { 'Decides that UNOCI } \\
\text { shall have the following } \\
\text { mandate ... To assist } \\
\text { the Government } \\
\text { in ... developing a } \\
\text { comprehensive national } \\
\text { security strategy' }\end{array}$ \\
\hline
\end{tabular}

In the case of the Central African Republic, support was provided to develop a national security sector reform plan. This support was mostly confined to the provision of political facilitation and technical and financial assistance. UNDP financed a national SSR seminar, which was intended to facilitate the development of the national plan. ${ }^{19}$ UNDP's Bureau for Crisis Prevention and Recovery also gave training to the staff of the seminar's steering committee (comité preparatoire), provided a full-time technical assistant and offered guidance for the drafting of the concept paper to be presented at the seminar. ${ }^{20}$ The national security sector reform plan was approved in April 2008 and addresses a broad spectrum of SSR-related activities broken down by ministry. These activities range from changes in recruitment, training and disciplinary practices to the creation of new laws, codes of conduct and administrative bodies.

In the case of Liberia, the major role of the UN Mission in Liberia (UNMIL) in supporting the development of a national security strategy was the provision of technical support and advice. This included participating in governmental committees, supporting the development of an implementation matrix that accompanied the strategy and using UNMIL radio to help raise awareness of the process. ${ }^{21}$ UNDP also helped to fund the national consultations that were used to provide input to the threat analysis and provided SSR guidance to support national authorities engaged in the process. ${ }^{22}$ The strategy was approved in January 2008.

18 The table includes integrated peacekeeping missions and special political and/or peacebuilding missions that have a significant SSR component to their mandate and included a reference to NSPs as defined in this paper.

19 Sylvie More, 'The Central African Republic: Development of the National Security Sector Reform Plan', case study report. See note 1.

20 Ibid.

21 Thomas Jaye, 'Liberia: Development of the National Security Strategy', case study report. See note 1. 22 Ibid. 
In Timor-Leste the United Nations played a strong role in supporting the policy process through support to drafting, institutional capacity-building, organising consultation meetings and providing technical advisers. In this case, the United Nations interpreted the need to support the process as part of the UN Integrated Mission in Timor-Leste's (UNMIT) mandate to assist the government in conducting a comprehensive review of the future role and needs of the security sector. The United Nations has constantly had to adapt its support in the face of shifting priorities and an evolving political momentum. ${ }^{23}$ The final draft of the policy was sent to the Council of Ministers in February 2011, but at the time of writing is still pending approval.

A commonality across the three case studies has been the range of challenges faced by the United Nations, including general obstacles such as security conditions hampering consultations, funding shortages, a scarcity of national and international experts (especially with local language skills) and constantly shifting priorities both within governments and UN missions. Another common theme has been that even when the NSPmaking process has advanced well, implementation was not necessarily without problems. For example, in CAR the seminar was greeted as a huge success, but several challenges have been noted in implementing the chronogramme. These included funding hurdles as well as the perception that the chronogramme was set in stone without offering flexibility for implementation in a changing environment. ${ }^{24}$ In Liberia the process was relatively successful, but implementation has not been without its difficulties either. For example, long delays have been encountered in implementing the tasks outlined in the NSP's implementation matrix, such as institutional reviews and necessary amendments to legislation. ${ }^{25}$ In Timor-Leste, the policy itself has been waiting for adoption for months, and it could be argued that this is partly linked to challenges concerning the national ownership of the policy process and related activities. ${ }^{26}$

While the United Nations has supported several relatively successful NSP processes, the organisation's track record in this area remains jagged. Despite external support, approval for such documents has not always materialised, and often there is neither the funding nor the political will to subsequently implement these activities. If NSPs are to provide vital entry points for institution-building, the process of developing NSPs has to be got right in the first place. It is during this process that the conditions are set for whether or not the NSP will be taken forward or remain yet another externally supported policy document. Against this backdrop, the dynamics of external support to national NSP-making processes deserve further analysis.

23 Björn Hofmann, 'Timor-Leste: Development of the National Security Policy', case study report. See note 1 .

24 More, note 19

25 Jaye, note 21

26 In particular, ownership concerns have been raised regarding the security sector review. See Gordon Peake, 'A Lot of Talk But Not a Lot of Action: The Difficulty of Implementing SSR in Timor-Leste', in Hans Born and Albrecht Schnabel (eds), Security Sector Reform in Challenging Environments (Geneva: Geneva Centre for the Democratic Control of Armed Forces, 2009), p. 222; Hofmann, note 23 .

\section{Evaluating the Tensions and Opportunities of UN Support to NSPs from an Institution- Building Perspective}

NSP-making is a demanding process at the level of political commitment and human and financial resources. However, the need for external support in many peacebuilding contexts adds another layer of complexity. This section attempts to shed light on the interrelationship between external support and national NSP-making processes from an institution-building perspective. It first examines common tensions identified in the case studies and then identifies opportunities to perceive the NSP process as part of longer-term institution-building.

\subsection{Tensions}

Many of the challenges faced in peacebuilding contexts are recognised to have deep roots connected to less understood facets of external intervention. ${ }^{27}$ These tensions relate to the crux of the relations between external 'institution builders' and the 'institutions' themselves. In order to illustrate this concern, this section addresses some of the main tensions emerging in the case studies. These can be grouped into three main areas: external support versus national ownership, universal standards versus national values and rigidity of international bureaucracy versus flexibility to adapt to a rapidly evolving national political and security momentum.

\section{External Support versus National Ownership}

In UN support to NSP-making in peacebuilding contexts, NSP processes must move forward fairly rapidly in order to be of value to ongoing or imminent initiatives to rebuild or reform security institutions. This raises the risk of national ownership being sidelined in an effort to maintain the political momentum of such processes. The combined lack of national expertise and capacity often results in an overly large role for international actors that seek to fill the gaps. This fact, coupled with international actors' propensity for short attention spans (particularly in the case of peacekeeping missions that have short-term mandates), can lead to external pressure to maintain political momentum and finalise the NSP process in the short timeframe available without granting the necessary time and space to national actors.

The example of Timor-Leste is a case in point, as the process was initially characterised by significant external involvement of both UN and non-UN actors in an effort to fill evident capacity gaps and maintain the political momentum, which was subject to ups and downs. In this context, there was a risk that the NSP process was being driven more by foreign agendas than by national expectations, often resulting in delays in the process. ${ }^{28} \mathrm{~A}$ balance was eventually found when

\footnotetext{
27 See for instance Roland Paris and Timothy D. Sisk, 'Managing Contradictions: The Inherent Dilemmas of Postwar Statebuilding', research paper (New York: International Peace Academy, November 2007), p. 3, available at www.ipinst. org/media/pdf/publications/iparpps.pdf.

28 Hofmann, note 23; Peake, note 26, pp. 222 and 231
} 
the Timorese authorities took the lead, with external advisers only providing guidance through the creation of an 'NSP core group'. ${ }^{29}$ However, the political will to push the draft through approval by the Council of Ministers had not yet materialised at the time of writing, raising questions over whether the process would have benefited from more dialogue and confidence- and capacity-building initiatives.

While national ownership is of key importance in any intervention, in the case of NSP-making it is particularly crucial due to the opportunity such processes provide to guide the outlook of a whole sector. Moreover, if ownership is not tackled early on through appropriate outreach and facilitation efforts, the effects may be reflected in subsequent lack of support for adoption or implementation down the line. A mitigation strategy may include enhanced assessments of the political will to lead the process, to avoid situations where the United Nations engages in supporting a process that lacks adequate commitment.

\section{International Standards versus National Values}

Supporting NSPs is not only extremely sensitive in that they touch on national security issues, but also because they touch on the core values of the state. In this paper, 'values' are understood as reflecting the common and uniting beliefs of the nation, but even within a nation it is possible that these are conflicting. ${ }^{30}$ An example is provided in the case of Liberia, where there was significant disagreement over whether or not the principles of democratic governance should be firmly reflected in the strategy. This dilemma was reflected in the process itself, whereby it was a struggle to ensure that the strategy would be based on a dialogue with the population through national consultations. ${ }^{31}$ The Governance Commission that was leading the process on the national side was a proponent of this method, but faced significant resistance from influential security officials ('securocrats') and government representatives who were not open to such an approach. ${ }^{32}$

Such dilemmas raise difficult questions for the United Nations. While for the United Nations it is clear that this is a process that needs to be consultative and governance-driven, this objective may be nuanced in countries where it is not considered entirely feasible or desirable. This raises the question as to where the United Nations should draw the line between respecting national values and insisting on internationally agreed standards. This challenge has been discussed at length in the area of peacemaking, for instance on the subject of granting amnesty. While it is difficult to provide a 'black-or-white' answer in the case of support to NSP-making or to democratic governance initiatives more broadly, the question of to what extent the United Nations can support a process which does not meet its standards is still valid. This was a point of contention

29 Hofmann, note 23.

30 James D. Noteboom, 'Developing National Security Strategies in the African Context', African Security Review, 17(3), p. 86, available at www.iss.co.za/ pgcontent.php?UID=18571.

31 Jaye, note 21

32 Ibid. among staff working on developing the UN guidance note on this topic, and the approach taken in the note is to steer away from the identification of 'standards' and rather to underline the context-specific nature of UN support. While the rationale is clear, the approach nonetheless offers little guidance to UN field staff when deciding what the limits of their support will be. A method to help overcome part of this challenge is to support South-South exchange that can help raise awareness on how other countries in the region have approached such 'taboo' issues in their own NSP processes. ${ }^{33}$

\section{Rigidity of International Bureaucracy versus Flexibility to Adapt to a Rapidly Evolving National Political and Security Momentum}

NSP development is a process which is likely to stop and start depending on the shifting political and security environment. International actors seeking involvement in such processes therefore need to be ready to scale up their support the minute the momentum picks up. In practice, this has often proved to be a challenge for the United Nations. Arguably, it is difficult for UN SSR teams to provide flexible capacity that can be increased and decreased when needed, due to funding and bureaucratic constraints. This challenge is compounded in cases where support to NSPs is undertaken in the context of broader SSR mandates: not all SSR processes demand such rapid upscaling and downscaling of support, so it is difficult to justify this degree of flexibility when the United Nations is not explicitly mandated to assist the NSP process.

However, there are some approaches that can be considered. For example, in the case of the CAR, the United Nations decided initially to limit the budget of the national SSR plan process to US $\$ 100,000 .^{34}$ This made the project eligible for a specific UNDP Crisis Prevention and Recovery Fund that allowed rapid disbursement. The project was therefore able to capitalise on the limited political will available at the time. But should the political or security situation suddenly change, the project could easily be scaled up or down as appropriate. ${ }^{35}$ Enabling flexibility of support efforts requires further emphasis. As reflected in the statement of the Secretary-General at a UN Security Council special debate on institution-building, international support needs to become 'more nimble and agile'. ${ }^{36}$

\subsection{Opportunities}

Examining NSP development from an institution-building perspective offers an innovative way of looking at it as more of a process-oriented approach. That is to say, it recognises that

33 This was considered a useful exercise in Liberia, for instance, to overcome resistance to including civilians in security debates. See Jaye, note 21.

34 More, note 19

35 Ibid.

36 UN Secretary-General, 'Given Marked Increase of Institution-Building Mandates in United Nations Missions, More Must be Done to Ensure Engagement with Other Actors', UN Doc. SG/SM/13358 - SC/10161 - PBC/76, 21 January 2011, available at www.un.org/News/Press/docs/2011/sgsm13358. doc.htm. 
NSP-making should not be perceived as the end state (or as the entry point to move on to another set of reforms), but rather as part of the institution-building process itself. Examples of looking at NSP-making from this long-term perspective include placing more emphasis on the process as opposed to the product, supporting political participation and investing in building national capacity.

\section{Promoting Process over Product}

NSP-making is increasingly ranking very high on international actors' 'to-do lists', whether because they want the document to serve as a strategic foundation for other projects or because it is written in as a benchmark for measuring progress towards mission objectives. Whatever the rationale, international pressure for the swift completion of NSPs is often evident. From an institution-building perspective, however, prioritising product over process can be seen as a missed opportunity. For example, in Timor-Leste some of the initial support involved external experts drafting parts of a policy document rather than transferring these skills to national stakeholders. ${ }^{37}$ Regret that the United Nations had not spent more time on capacitybuilding was also expressed in the Liberia case study, which noted that this would have enabled the country to continue reviewing and drafting its policies after UN withdrawal. ${ }^{38}$

Process over product is often preached in literature on institution-building and national ownership. Donais, for instance, notes that 'quick-fix, outsider-led institution-building may be appealing on paper, but the longer, slower path to sustainable security institutions promises greater returns over the long run'. ${ }^{39}$ The case studies examined highlight that the same holds true in the area of NSPs: the value of NSP-making to peacebuilding efforts lies not just in the final document but also in the contribution made to the process of institution-building. It provides an opportunity to start capacity-building and, fundamentally, dialogue and confidence-building. The benefits of the process to SSR efforts should not obscure its significant contribution to institution-building. The NSP-making process presents an exceptional opportunity for the United Nations to help develop the human capacity and institutions necessary for a country to benefit from SSR in the long run. Support should be adapted to recognise and build on this opportunity.

\section{Redefining Political Participation}

Seeing NSP-making through an institution-building lens can support the understanding that the process itself can help to strengthen political participation in national decision-making. Indeed, institutionalisation can be understood as the 'process through which values and goals come to be shared and social relationships and actions become normatively regulated'. ${ }^{40}$

37 Hofmann, note 23 .

38 Jaye, note 21.

39 Timothy Donais, 'Operationalising Local Ownership in SSR', in Timothy Donais (ed.), Local Ownership in Security Sector Reform (Geneva: Geneva Centre for the Democratic Control of Armed Forces, 2008), p. 283. 40 Cited in Blase, note 7, p. 355.
Interacting with the population enables the development of expectations and obligations which are vital for the proper functioning of service delivery institutions. The NSP process can lay a foundation for these interactions by providing a platform for dialogue on expectations of the population (and the security institutions themselves), which are subsequently integrated and developed into a set of goals outlined in the document.

In many experiences of NSP-making the time allowed for national dialogue and consultation was not deemed sufficient. In the case of Liberia there was significant resistance to a consultative approach, which was deemed to be a waste of resources and perceived as a compromise to national security. ${ }^{41}$ In the CAR, security concerns meant that reaching out to broader communities outside the capital was a problem. However, an alternative approach was found by inviting a representative of local authorities in each province to attend the national SSR seminar. ${ }^{42}$

While such processes can of course raise the risk of creating high expectations, as they empower people to make demands that may be unrealistic or contradictory, ${ }^{43}$ they are still a vital component of institution-building and should be seen as such. From this perspective, supporting the necessary time and resources for such dialogue is important, as is the need to support expectations management to avoid challenges down the line when expected results are not achieved at the anticipated pace.

\section{Building National Capacity}

NSP-making sets the foundations for institution-building by defining what capacity is needed at the institutional level. However, more significantly, what is often overlooked is that it can support individual capacity-building, which can strengthen overall institutional capacity in the long run. In practice, as noted at a recent expert-level seminar on African perspectives on SSR, 'the absence of local technical skills is often presumed, as a matter of faith, rather than as a tested observation'. ${ }^{44}$ This often results in a risk of substitution by international actors rather than efforts to support capacity-building, which is a recurring theme in the case studies. As mentioned above, in Timor-Leste a significant dilemma was that international actors could be perceived as initially replacing rather than supporting national capacity. Similarly, in Liberia the need for more focus on capacity-building was identified as a lesson from the process.

Looking at NSP-making from an institution-building perspective can thus refocus the importance of providing support to individual capacity-building. The skills needed for NSP-making include drafting, planning, dialogue facilitation etc. All these

41 Jaye, note 21.

42 More, note 19

43 Organisation for Economic Co-operation and Development, Do No Harm: International Support for Statebuilding (Paris: OECD, 2009), p. 50; World Bank, World Bank Development Report 2011: Conflict, Security and Development (Washington, DC: World Bank, 2011) pp. 100, 105-106.

44 Security Sector Reform Unit, Office of Rule of Law and Security Institutions, DPKO, 'African Perspectives on Security Sector Reform', final report of HighLevel Forum on African Perspectives on SSR and the Expert-Level Seminar on African Perspectives on SSR, New York, 13-14 May 2010, p. 9. 
skills are very valuable for the functioning of institutions. They can contribute to expertise in strategy development, which is useful in formulating institutional policies and strategies, as well as supporting skills for undertaking monitoring and evaluation or participatory consultations. This is crucial in ensuring support to sustainable institutions that can function long after the international actors are gone.

\section{Conclusion}

Given the UN's (and other international actors') increasing interest in supporting NSP-making processes, there is a need for greater reflection on how such support should be provided. In practice, international support to such processes is often based on the understanding that NSPs represent entry points for engaging in subsequent institution-building. This is problematic, because it reinforces the tensions visible between international intervention and national ownership and can lead to missed opportunities to strengthen institution-building efforts from the outset.

When discussing the dilemmas of post-war state-building, Roland Paris and Timothy Sisk note that while there are no simple solutions, 'greater knowledge of the tensions and contradictions of statebuilding should make it easier to manage the dilemmas in a more informed, nuanced, and effective manner'. ${ }^{45}$ The same holds true in the context of UN support to national security policy-making. The development of technical UN guidance for field staff is already a significant step forward, as it identifies some of the potential challenges practitioners may find when providing support in this area and lists opportunities.

Ultimately, seeing UN support to NSP-making from an institution-building perspective offers an innovative approach to enhancing support efforts. It would help identify key tensions linked to the external intervention versus national ownership dilemma. An NSP cannot be developed overnight: sufficient time needs to be allocated to it, and trust and confidence-building must be encouraged and expectations managed. It also involves significant preparation, including consultation with institution representatives and the broader population. It is a process that can be drawn out, and this needs to be understood by both national and international actors.

An institution-building perspective on NSP-making should help to ensure that national security policies are not perceived as a box to check on a list, but rather as an integral process in itself which supports the building of sustainable security institutions through capacity-building and national dialogue, essentially redefining national expectations and obligations in the provision of state and human security.

\section{Sind Sicherheitsbedrohungen vorhersagbar?}

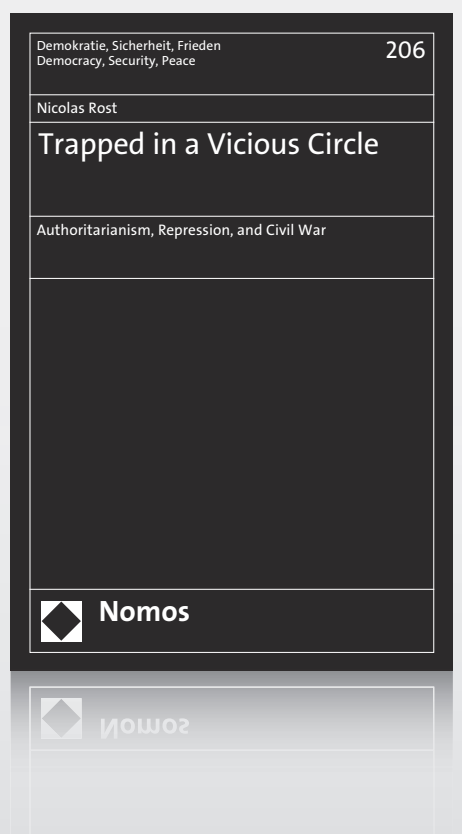

Trapped in a Vicious Circle

Authoritarianism, Repression, and Civil War

Von Nicolas Rost

2012, 242 S., brosch., 49,-€, ISBN 978-3-8329-7744-3

(Demokratie, Sicherheit, Frieden, Bd. 206)

Wie sind verschiedene Bedrohungen menschlicher Sicherheit - Bürgerkrieg, Menschenrechtsverletzungen und andere politische Gewalt - untereinander verbunden? Wie können diese Verbindungen genutzt werden, um das Risiko zusätzlicher Gewalt abzuschätzen? Und was können wir tun, um gewalttätige Konflikte zu beenden? Dieses Buch untersucht diese Fragen empirisch.

Weitere Informationen: www.nomos-shop.de/19500

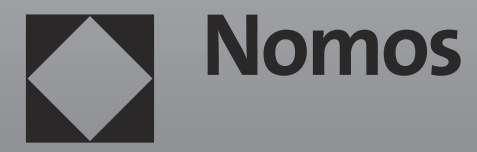

